\title{
Molecular Distributions and Compound-Specific Stable Carbon Isotopic Compositions of Plant Wax n-Alkanes in Marine Aerosols along a North-South Transect in the Arctic-Northwest Pacific Region
}

\author{
Jung-Hyun Kim ${ }^{1, *}$, Jiyeon Park ${ }^{1}$, Sol-Bin Kim ${ }^{2}$, Kyung-Hoon Shin ${ }^{2}$, Sookwan Kim ${ }^{1}$ and \\ Yeontae Gim $^{1}$ D \\ 1 Korea Polar Research Institute (KOPRI), 26 Songdomirae-ro, Yeonsu-gu, Incheon 21990, Korea; \\ jypark@kopri.re.kr (J.P.); skwan@kopri.re.kr (S.K.); ytkim@kopri.re.kr (Y.G.) \\ 2 Department of Marine Sciences and Convergent Technology, Hanyang University, 55 Hanyangdaehak-ro, \\ Sangnok-gu, Ansan 15588, Korea; ksv9502@hanmail.net (S.-B.K.); shinkh@hanyang.ac.kr (K.-H.S.) \\ * Correspondence: jhkim123@kopri.re.kr; Tel.: +82-32-760-5377
}

Received: 7 April 2020; Accepted: 8 May 2020; Published: 13 May 2020

\begin{abstract}
A geographical source of $n$-alkanes in marine aerosols was assessed along a North-South transect in the Arctic-Northwest Pacific region. Marine aerosol samples were collected during the ARA08 cruise with the R/V Araon between 28 August and 28 September 2017. We investigated molecular distributions of $n$-alkanes (homologous series of $C_{16}$ to $C_{34}$ ) and compound-specific stable carbon isotopes $\left(\delta^{13} \mathrm{C}\right)$ of $n-\mathrm{C}_{27}, n-\mathrm{C}_{29}$, and $n-\mathrm{C}_{31}$. Unresolved complex mixtures (UCM) showed a latitudinal trend from the Arctic Ocean to the northwest Pacific Ocean, highlighting an increasing influence of the plume of polluted air exported from East Asian countries. The anthropogenic input was further evidenced by high $\mathrm{U} / \mathrm{R}$ ratios $(>5)$ and low $\mathrm{CPI}_{17-23}(0.6-1.4)$. The occurrence of high molecular weight (HMW) $n$-alkanes with high $\mathrm{CPI}_{27-31}(>3)$ indicated the biogenic input of terrestrial higher plant leaf waxes in all studied samples. The $\delta^{13} \mathrm{C}$ of HMW $n$-alkanes was influenced by both the relative contributions from the $\mathrm{C}_{3} / \mathrm{C}_{4}$ plant sources and from fossil fuel combustions. The back-trajectory analyses provided evidence that changes in molecular distributions and $\delta^{13} \mathrm{C}$ of $n$-alkanes were due to the long-range atmospheric transport of anthropogenic and biogenic organic materials from North American and East Asian countries to the Arctic Ocean and the remote northwest Pacific Ocean, respectively.
\end{abstract}

Keywords: marine aerosol; $n$-alkanes; compound-specific carbon isotopes; Arctic Ocean; northwest Pacific Ocean

\section{Introduction}

The $n$-alkanes originate from both anthropogenic and biogenic sources, including petroleum residue [1], biomass burning [2], and terrestrial plant wax, fungi, bacteria, algae, and plankton [3]. High molecular weight (HMW) $n$-alkanes $\left(>n-C_{25}\right)$ are typical land-derived lipid biomarkers which can be carried from adjacent continents to remote oceanic settings by long-range atmospheric transport [4-7]. Investigations of HMW $n$-alkanes in marine aerosols have been widely conducted in the Atlantic Ocean [5,8,9], the Pacific Ocean [10-12], and the Southern Ocean [11]. HMW n-alkanes are also often found in marine surface sediments close to continental land in the Atlantic Ocean [13-15], the Pacific Ocean [16,17], and the Southern Ocean [18], reflecting latitudinal vegetation changes on the continent. Hence, the distributions and isotopic signatures of HMW $n$-alkanes extracted from marine sediment cores have successfully been used to reconstruct changes in terrestrial vegetation 
as part of paleoclimatological reconstructions [19-23]. Although long-range atmospheric transport is an important pathway for the land-derived HMW n-alkanes over the Arctic Ocean, there have been very few marine aerosols observed in the Arctic Ocean [24]. In particular, no studies have examined isotopic signatures of HMW n-alkanes in marine aerosols in the Arctic Ocean. Hence, our knowledge of the sources and transport pathways of HMW $n$-alkanes in marine aerosols is still limited in this body of water.

In this study, we collected marine aerosol samples along a North-South transect in the Arctic-Northwest Pacific region in August and September 2017. This study compares variations in molecular distributions and carbon isotope compositions of HMW n-alkanes in marine aerosols over the Arctic Ocean and the northwest Pacific Ocean by using air-mass back trajectories. This study provides an insight into the potential sources of marine aerosols and the atmospheric transport pathways of land-derived HMW n-alkanes over the Arctic Ocean and the remote northwest Pacific Ocean.

\section{Experiments}

\subsection{Aerosol Sample Collection}

Six aerosol samples were collected along a North-South transect in the Arctic-Northwest Pacific region during the ARA08 cruise with the R/V Araon between 28 August and 28 September 2017 (Table 1, Figure 1). The sampling conditions were almost homogeneous without any severe weather heterogeneity [25]. Air sampling was performed on a Pallflex quartz fiber filter $(20 \mathrm{~cm} \times 25 \mathrm{~cm})$ using a high-volume air sampler (HV-1000R, Sibata Scientific Technology Ltd., Soka, Japan). The aerosol sampling inlet was placed on the front deck of the ship (13 m above sea level), ahead of the ship's engines, and a wind controller was used to avoid contamination from ship-engine exhaust during the cruise. In addition, kitchen ventilation systems were connected by a plastic cylindrical pipe ( $15 \mathrm{~m}$ length) and moved back on the deck (far away from the sampling inlet) to minimize the potential effects of cooking emissions on the atmospheric measurements during the sampling periods. Similar to another study [9], the aerosol collector was connected to a wind vane programmed to have the unit switched on when wind was from a predetermined arc of 100 degrees to each side from the front of the ship with relative wind speed higher than $2 \mathrm{~m} \mathrm{~s}^{-1}$, and off at other times to prevent contamination from the ship's chimney. The sampling flow rate was $1000 \mathrm{lpm}$ and the total sampling time was 2-3 days. After sampling, the sample filters were stored on board at $-20^{\circ} \mathrm{C}$ until analysis in the laboratory.

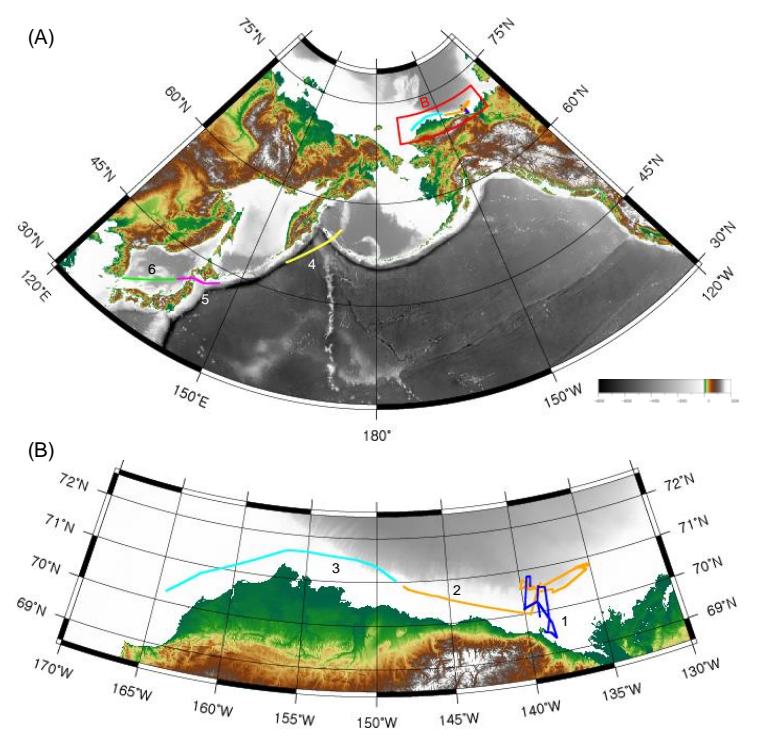

Figure 1. (A) Cruise tracks of the ARA08 cruise corresponding to each sample with the quartz fiber filter identification numbers used. (B) Detailed cruise tracks for the Arctic samples with the quartz fiber filter identification numbers used. 
Table 1. Information on marine aerosol sampling.

\begin{tabular}{cccccccccc}
\hline $\begin{array}{c}\text { Sample } \\
\text { No. }\end{array}$ & Latitude & Longitude & $\begin{array}{c}\text { Date } \\
\text { (yyyy.mm.dd) }\end{array}$ & $\begin{array}{c}\text { Time } \\
\text { (UTC) }\end{array}$ & Latitude & Longitude & $\begin{array}{c}\text { Date } \\
\text { (yyyy.mm.dd) }\end{array}$ & $\begin{array}{c}\text { Time } \\
(\text { UTC) }\end{array}$ & $\begin{array}{c}\text { Volume } \\
\left(\mathbf{m}^{3}\right)\end{array}$ \\
\hline $\begin{array}{c}\text { ARA08 } \\
\text { QFF-1 }\end{array}$ & 70.60 & -139.30 & 2017.09 .03 & $16: 00$ & 69.88 & -139.10 & 2017.09 .05 & $15: 02$ & 2632 \\
$\begin{array}{c}\text { ARA08 } \\
\text { QFF-2 }\end{array}$ & 70.50 & -139.00 & 2017.09 .07 & $16: 18$ & 71.00 & -148.50 & 2017.09 .13 & $16: 12$ & 3051 \\
$\begin{array}{c}\text { ARA08 } \\
\text { QFF-3 }\end{array}$ & 71.00 & -148.70 & 2017.09 .13 & $17: 10$ & 66.77 & -168.40 & 2017.09 .15 & $16: 45$ & 2755 \\
$\begin{array}{c}\text { ARA08 } \\
\text { QFF-4 }\end{array}$ & 55.86 & 170.17 & 2017.09 .20 & $20: 20$ & 49.43 & 158.14 & 2017.09 .22 & $20: 21$ & 2686 \\
$\begin{array}{c}\text { ARA08 } \\
\text { QFF-5 }\end{array}$ & 42.88 & 146.19 & 2017.09 .24 & $20: 59$ & 40.16 & 138.14 & 2017.09 .26 & $9: 30$ & 2107 \\
$\begin{array}{c}\text { ARA08 } \\
\text { QFF-6 }\end{array}$ & 40.09 & 138.01 & 2017.09 .26 & $10: 23$ & 34.90 & 127.70 & 2017.09 .28 & $1: 00$ & 2267 \\
\hline
\end{tabular}

\subsection{Backward Air-Mass Trajectory Analysis}

The geographical source areas of tropospheric air that arrived at the ship during sampling periods for each aerosol sample were estimated from air-mass back-trajectory analyses using version 4 of the Hybrid Single-Particle Lagrangian Integrated Trajectory (HYSPLIT) model [26]. The 2-day air-mass back trajectories $(48 \mathrm{~h})$ were determined at hourly intervals from the ship's position at an arrival height of $50 \mathrm{~m}$ to estimate the transport history of the air masses arriving at the observation site $[25,27]$. The potential origins of the aerosols were divided into four categories based on the residence time of the 2-day back trajectories over the three major domains: Arctic Ocean (including the Beaufort Sea, the Chukchi Sea, and sea-ice region), Pacific Ocean (including the Bering Sea and the Sea of Okhotsk), East Asia (including China and the eastern part of Siberia), and North America (including Alaska and Canada). Geographical information about the ocean, land, and sea-ice was obtained from the sea-ice index, which was provided by the National Snow and Ice Data Center (NSIDC). The sea-ice extent was defined as the area having an ice concentration of $\geq 15 \%$ [28].

\subsection{Analysis of n-Alkanes}

All six quartz fiber filters were freeze-dried, cut into small $(1 \mathrm{~cm} \times 1 \mathrm{~cm})$ pieces, and ultrasonically extracted $(5 \times)$ with a mixture of dichloromethane (DCM):methanol (MeOH) (2:1, v:v) for $20 \mathrm{~min}$. The total lipid extracts were concentrated under a gentle $\mathrm{N}_{2}$ stream and passed over a small $\mathrm{Na}_{2} \mathrm{SO}_{4}$ Pasteur pipette column. The extracts were separated into apolar and polar fractions on an activated $\mathrm{Al}_{2} \mathrm{O}_{3}$ column using hexane:DCM $(9: 1, \mathrm{v}: \mathrm{v})$ and DCM:MeOH $(1: 1, \mathrm{v}: \mathrm{v})$, respectively. The apolar fraction containing $n$-alkanes was dried and further purified over an Ag+ impregnated silica pipette column to separate aliphatic and aromatic hydrocarbons using hexane as eluent.

The apolar fractions were analyzed with an Agilent 7890A gas chromatograph (GC, Agilent Technologies, Santa Clara, CA, USA) equipped with a flame ionization detector (FID) using a DB-5 column fused silica capillary column $(30 \mathrm{~m}$ length, $0.25 \mathrm{~mm}$ internal diameter, and $0.25 \mu \mathrm{m}$ film thickness, Agilent). The samples were injected under constant flow at an initial oven temperature of $70{ }^{\circ} \mathrm{C}$ in a splitless mode with helium as a carrier gas. The GC oven temperature was subsequently raised to $130{ }^{\circ} \mathrm{C}$ at a rate of $20^{\circ} \mathrm{C} / \mathrm{min}$, and then to $320^{\circ} \mathrm{C}$ at $4{ }^{\circ} \mathrm{C} / \mathrm{min}$, with a final hold time of $45 \mathrm{~min}$. Quantification of chromatographically resolved aliphatic hydrocarbons was made by using external standards (solution of $n$-alkanes from $C_{8}$ to $C_{40}$, pristane, and phytane; Supelco 502065, AccuStandard, New Haven, CT, USA). The concentration of unresolved complex mixtures (UCM) was calculated with the mean response factors of $n$-alkanes. The apolar fractions were also analyzed with an Agilent 7820A GC coupled to an Agilent 5977E MSD mass spectrometer (MS, Agilent Technologies, Santa Clara, CA, USA) operated at $70 \mathrm{eV}$ with a mass range of $m / z 50-800$. The samples were subjected to the same temperature conditions and capillary column described for GC analysis. Compound identifications 
were based on a comparison of relative GC retention times and mass spectra of the $n$-alkane mixture $\left(\mathrm{C}_{8}-\mathrm{C}_{40}\right.$ ) analytical standards (Supelco 502065).

The average chain length (ACL) [29], the carbon preference index (CPI) [30], the percentage of wax $n$-alkanes (\%Wax) [31], and the percentage of petrogenic $n$-alkanes (\%PNA) [32] were calculated as follows:

$$
\begin{gathered}
\mathrm{ACL}=\frac{[27 \times \mathrm{C} 27+29 \times \mathrm{C} 29+31 \times \mathrm{C} 31]}{[\mathrm{C} 27+\mathrm{C} 29+\mathrm{C} 31]} \\
\mathrm{CPI}=\frac{1}{2} \times\left[\left(\frac{\mathrm{C} 27+\mathrm{C} 29+\mathrm{C} 31}{\mathrm{C} 26+\mathrm{C} 28+\mathrm{C} 30}\right)+\left(\frac{\mathrm{C} 27+\mathrm{C} 29+\mathrm{C} 31}{\mathrm{C} 28+\mathrm{C} 30+\mathrm{C} 32}\right)\right] \\
\text { Wax }-\mathrm{Cn}=[\mathrm{Cn}]-\left[\frac{\mathrm{C} n+1+\mathrm{Cn}-1}{2}\right] \\
\% W a x=\frac{\Sigma W a x-\mathrm{Cn}}{\Sigma \mathrm{NA}} \times 100 \\
\% \mathrm{PNA}=100-\% W a x
\end{gathered}
$$

where $\mathrm{C} n$ is the concentration of the n-alkane containing $\mathrm{n}$ carbon atoms, $\Sigma W a x-\mathrm{C} n$ is the concentration sum of wax $n$-alkane contribution arising from all odd $n$-alkanes, and $\Sigma$ NA is the concentration sum of total $n$-alkanes in the range of $C_{26}$ to $C_{32}$.

\subsection{Compound-Specific Stable Carbon Isotope Analysis}

The $\delta^{13} \mathrm{C}$ values of $n$-alkanes were determined using an isotope ratio mass spectrometer (IsoPrime GV Instruments, Manchester, UK) connected with a GC (Hewlett Packard 6890 N series, Agilent Technologies, Santa Clara, CA, USA) via a combustion interface (glass tube packed with copper oxide- $\mathrm{CuO}$, operated at $850^{\circ} \mathrm{C}$ ) [17]. The samples were subjected to the same temperature conditions and capillary column described for the GC and GC-MS analyses. Isotopic values are expressed as $\delta^{13} \mathrm{C}$ values in per mil relative to the Vienna-Pee Dee Belemnite (VPDB). Isotope values of the dominant $\mathrm{C}_{27}, \mathrm{C}_{29}$, and $\mathrm{C}_{31}$ homologues reported were determined by averaging duplicate analyses whenever concentrations were sufficient. Standard deviations of carbon isotope measurements were generally better than $\pm 0.4 \%$, as determined by repeated injections of the standard.

\subsection{Statistical Analysis}

The fractional abundances of each $n$-alkane component were obtained by normalizing each $n$-alkane concentration to the summed concentration of $n$-alkane compounds $\left(C_{26}-C_{32}\right)$ considered. To provide a general view of the variability of the distribution of $n$-alkanes, principal component analysis (PCA) was performed on the fractional abundances of $n$-alkanes using the $\mathrm{R}$ program [33]. We also performed hierarchical clustering of principal components (HCPC) on the PCA results to cluster samples with similar $n$-alkane distributions.

\section{Results}

The ship track during sample acquisitions is indicated in Figure 1, and the beginning and ending coordinates are given in Table 1 . The air masses mainly came from the north and then passed over the Arctic Ocean to the ship when the marine aerosol samples of QFF-1 and QFF-2 were collected (Figure 2). The back trajectories were different when QFF-3 was collected, showing increased contributions from the Pacific Ocean and the eastern part of Siberia. The air masses mainly originated from the Pacific Ocean, with a minor portion of East Asia, when QFF-4 was collected. The air masses from East Asia increased during the QFF-5 and GFF-6 sample collection.

The resolved $n$-alkanes were detected in a series of $C_{16}$ to $C_{34}$ with a predominance of $n-C_{27}$, $n-C_{29}$, and $n-C_{31}$ homologues (Figure 2). All aerosol samples studied showed a broad and unimodal UCM of hydrocarbons eluting between $n-C_{15}$ and $n-C_{25}$. The UCM concentrations varied between 4 and $105 \mathrm{ng} / \mathrm{m}^{3}$ (Figure 3A). The ratios of unresolved to resolved hydrocarbon components (U/R) 
were in the range of 5.0 to 9.9 (Figure 3B). The concentration of odd-carbon-numbered long-chain n-alkanes in $C_{27}-C_{31}\left(\Sigma C_{27}-31\right)$ ranged from 0.04 to $2.5 \mathrm{ng} / \mathrm{m}^{3}$, with higher values close to the East Asian continent (Figure 3C). The $\mathrm{ACL}_{27-31}$ (Equation (1)) was relatively stable along the North-South transect, with an average of $28.9 \pm 0.2$ (Figure 3D). The odd to even predominance of the $n$-alkanes, expressed as $\mathrm{CPI}_{27-31}$ (Equation (2)), was between 3 and 7 (Figure 3E). The \%Wax $27-31$ (Equations (3) and (4)) was in the range of $41-71 \%$ (Figure 3F). All $n$-alkane compounds except for $n-C_{27}, n-C_{29}$, and $n$ - $C_{31}$ were not present in sufficient concentrations to be measurable by GC-IRMS. The $\delta^{13} \mathrm{C}$ values of the dominant HMW $n$-alkanes $\left(n-C_{27}, n-C_{29}\right.$, and $\left.n-C_{31}\right)$ fell in the range of $-32.2 \%$ o to $-30.1 \%$, $-33.1 \%$ o to $-31.4 \%$, and $-34.8 \%$ o to $-31.8 \%$ o, respectively (Figure 4 ).

The PCA results based on the fractional abundances of HMW $n$-alkanes $\left(\mathrm{C}_{26}-\mathrm{C}_{32}\right)$ showed that the PC1 (55.5\%) was closely related to odd-carbon-numbered long-chain $n$-alkanes $\left(C_{27}\right.$ to $\left.C_{31}\right)$ with a negative loading and a positive loading of all even-carbon-numbered $n$-alkanes $\left(C_{26}\right.$ to $\left.C_{32}\right)$ (Figure 5 ). The PC2 (35.4\%) predominantly reflected the presence of $\mathrm{C}_{28}$ to $\mathrm{C}_{32}$ with a positive loading and $\mathrm{C}_{26}$ to $\mathrm{C}_{27}$ with a negative loading. The subsequent HCPC results showed that all Arctic marine aerosol samples were grouped as one cluster, associated with even-carbon-numbered long-chain $n$-alkanes. The Pacific marine aerosol samples were separately clustered into odd-carbon-numbered long-chain $n$-alkanes.
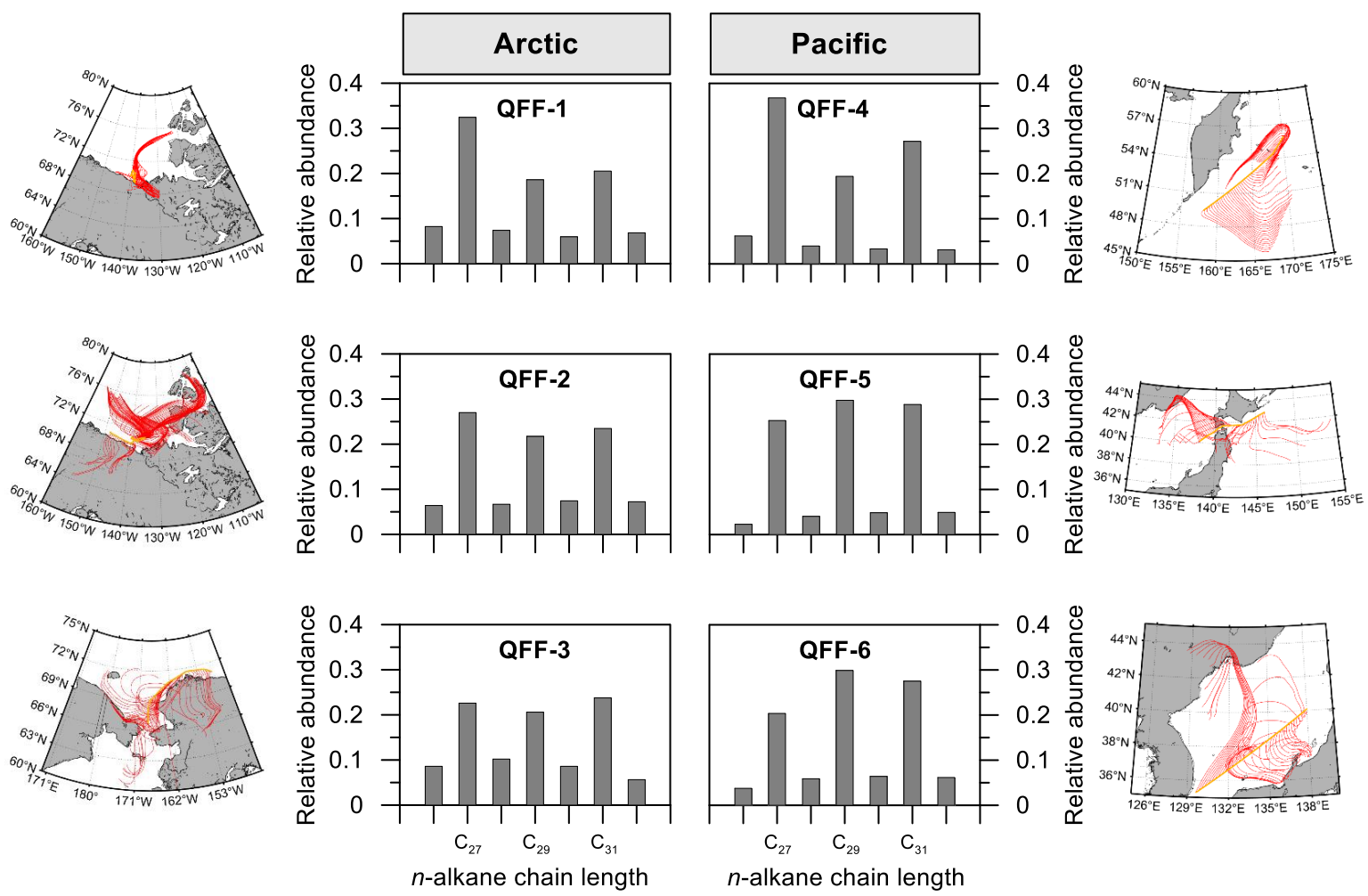

Figure 2. Backward air-mass trajectories at $50 \mathrm{~m}$ above ground level for each sample and fractional abundances of high molecular weight (HMW) n-alkanes for the range of $C_{26}-C_{32}$. The yellow lines indicate the ship track lines. 


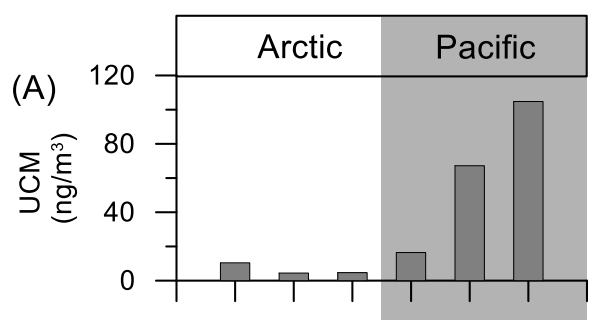

(D)
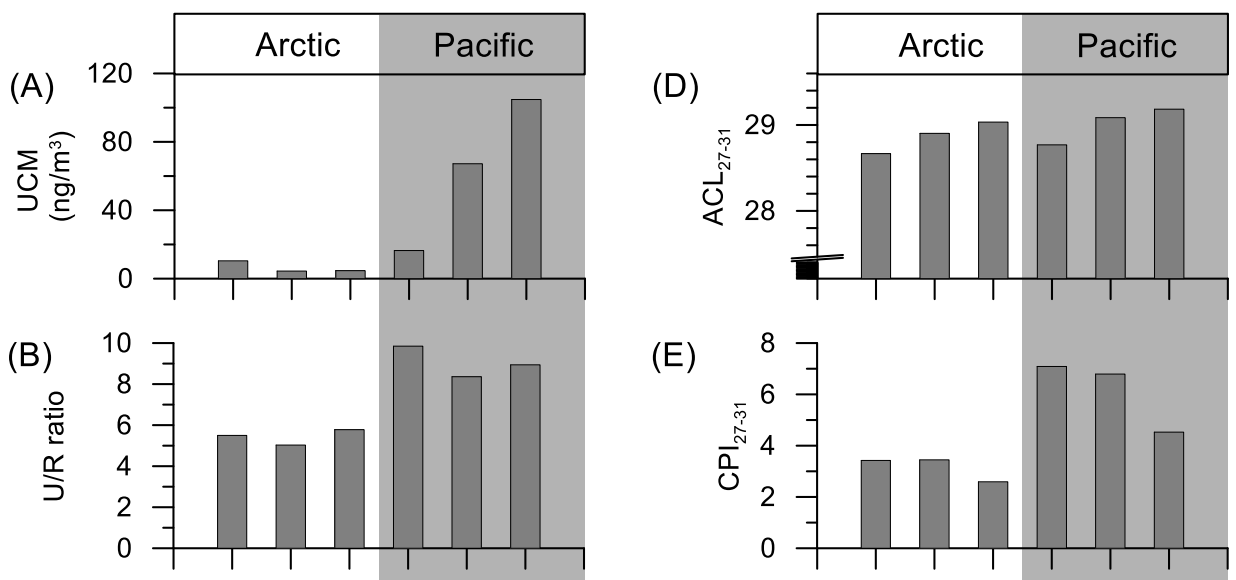

(E)
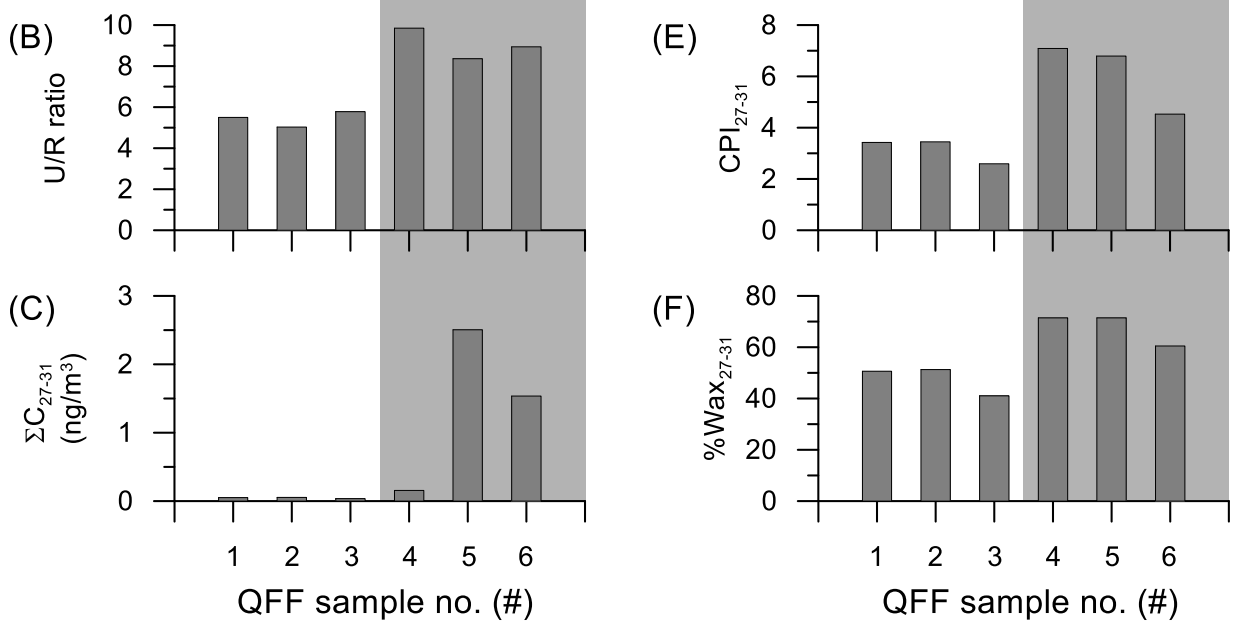

(F)

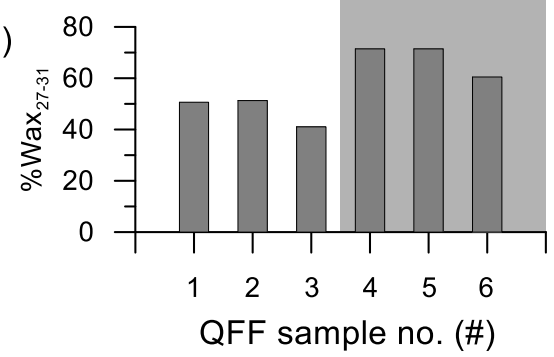

Figure 3. (A) Concentration of unresolved complex mix (UCM) hydrocarbons, (B) ratio of unresolved to resolved hydrocarbon components (U/R), (C) odd-carbon-numbered long-chain $n$-alkanes in the range of $C_{27}-C_{31}\left(\Sigma C_{27-31}\right),(D)$ average chain length $\left(\mathrm{ACL}_{27-31}\right)$, (E) carbon preference index $\left(\mathrm{CPI}_{27-31}\right)$, and $(\mathbf{F})$ the percentage of wax $n$-alkanes $\left(\% W^{2} x_{27}\right)$.

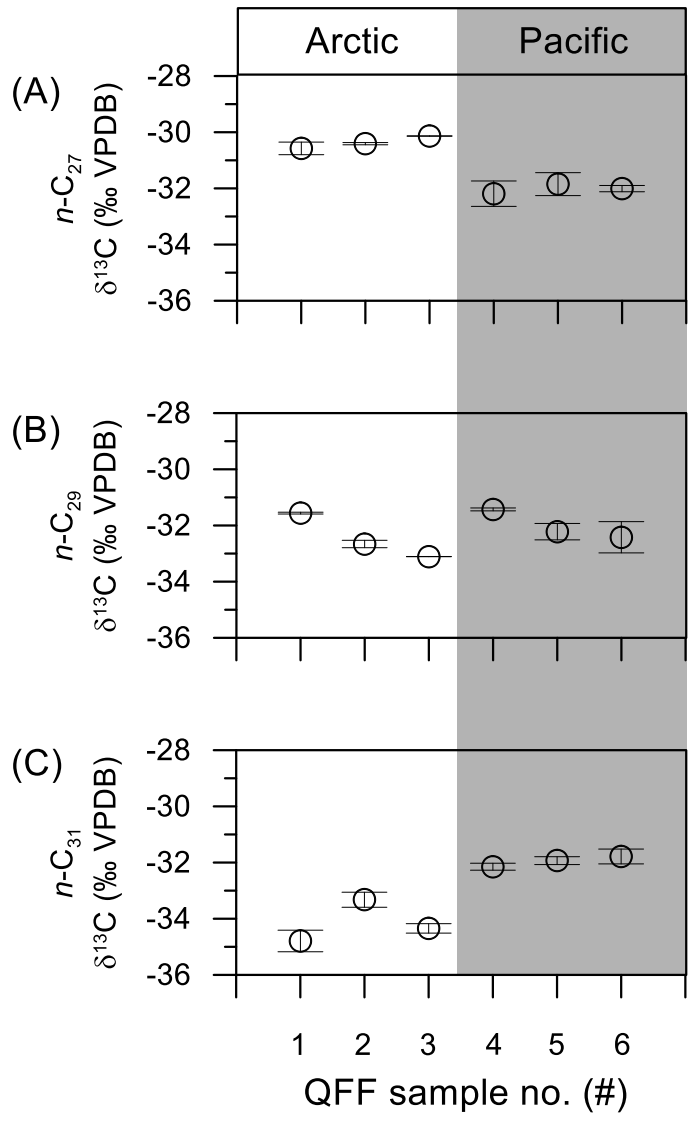

Figure 4. Average $\delta^{13} \mathrm{C}$ values of each sample for (A) $n-\mathrm{C}_{27}$, (B) $n$ - $\mathrm{C}_{29}$, and (C) $n-\mathrm{C}_{31}$. 

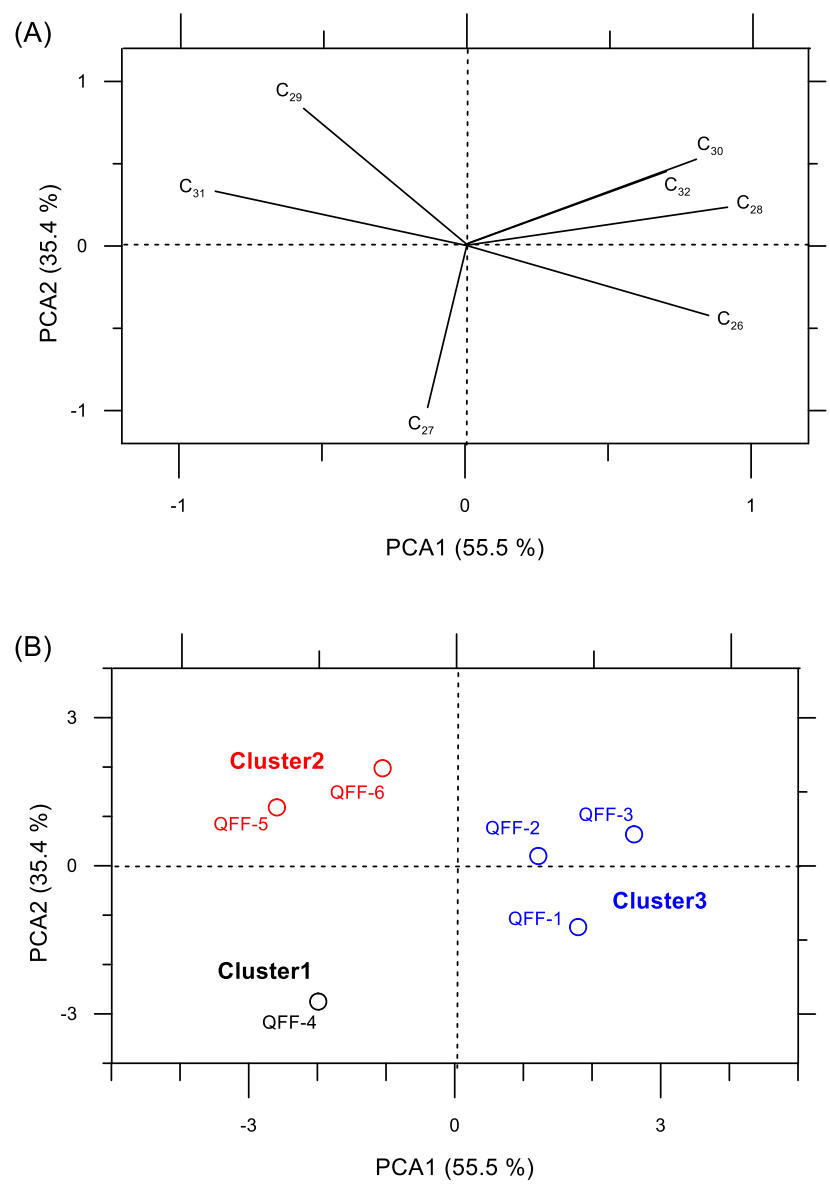

Figure 5. (A) Results of the Principal Component Analysis (PCA), and (B) the Hierarchical Clustering on Principal Components (HCPC) of the fractional abundances of HMW n-alkanes for the marine aerosol samples investigated.

\section{Discussion}

\subsection{Anthropogenic Hydrocarbons in Marine Aerosols}

Unresolved complex mixtures of hydrocarbons are composed of positional isomers of linear, branched, and/or cyclic alkanes with different carbon numbers and emitted to the atmosphere by incomplete fossil-fuel combustion [34-36]. The UCM hydrocarbons were detected in all marine aerosol samples investigated and showed a latitudinal trend of increasing values towards the south with a maximum value in GFF-6 in the northwest Pacific Ocean (Figure 3A). Our results are in good agreement with previous studies which showed the presence of UCM hydrocarbons in marine aerosol samples collected over the northwest Pacific Ocean, the East China Sea, and the East Sea of Korea [10-12]. The presence of UCM hydrocarbons was also reported in aerosol samples collected from ground stations on Jeju Island in South Korea, on Hokkaido Island, and Chichi-Jima Island in Japan [10,37,38], and in a southeastern coastal city of China (Xiamen) [39]. In general, the UCM concentrations of marine aerosol samples collected over the Northwest Pacific were one order of magnitude higher than those of aerosol samples collected at the Chichi-Jima station located in the remote northwest Pacific Ocean [10,37]. The concentrations of UCM hydrocarbons were three orders of magnitude higher in aerosol samples collected at Alert $\left(82.5^{\circ} \mathrm{N}, 62.3^{\circ} \mathrm{W}\right)$ in the Canadian high Arctic [40] than those of the marine aerosol samples collected over the Beaufort Sea. Thus, our results indicate a generally increasing input of anthropogenic pollution from the Arctic Ocean to the northwest Pacific Ocean. 
The ratio of unresolved to resolved hydrocarbon components $(\mathrm{U} / \mathrm{R})>4$ can be another sign of a substantial input of fossil-fuel combustion to marine aerosols [41-43]. In our samples, the U/R was on average $5 \pm 0.3$ in the Arctic Ocean and $9 \pm 0.6$ in the northwest Pacific Ocean (Figure 3B), providing additional evidence that the marine aerosols investigated were affected by long-range transport of fossil-fuel combustion aerosols. The CPI of $n$-alkanes can be another measure of petroleum inputs. Petroleum-derived $n$-alkanes have a regular distribution with a CPI of $1[1,44]$, whereas epicuticular waxes derived from higher land plants generally have CPI values of $>4$ [41]. The CPI values for the whole range of $C_{17}-C_{33}$ were 1.2-1.6 in the Arctic Ocean and 3.1-5.0 in the northwest Pacific Ocean. The CPI for the low molecular weight $n$-alkanes (i.e., $\mathrm{C}_{17}-\mathrm{C}_{23}$ ), where the UCM hump occurred, were lower, with values of 0.6-0.7 in the Arctic Ocean and 0.7-1.4 in the northwest Pacific Ocean, confirming anthropogenic inputs from fossil-fuel combustion in the marine aerosols studied.

The back trajectories calculated for the periods of the samples collected in the Arctic Ocean showed that the air masses mainly originated from the Arctic Ocean and North America (Table 2). On the contrary, the air-mass trajectory analyses generally showed that most of the air masses came from the East Asian countries over the northwest Pacific Ocean through the atmosphere under the influence of strong westerly and northerly winds. Accordingly, our results show that the Arctic Ocean and the northwest Pacific Ocean were influenced by the plume of polluted aerosols exported from North American and East Asian countries during the sampling periods, respectively.

Table 2. Percentages of dominant back trajectories found within each sampling period.

\begin{tabular}{ccccc}
\hline \multirow{2}{*}{ Sample No. } & \multicolumn{3}{c}{ Geographical Source Sectors for Air-Mass Trajectories } \\
\cline { 2 - 5 } & Pacific Ocean & Arctic Ocean & East Asia & North America \\
\hline ARA08 QFF-1 & 16.5 & 53.9 & 0 & 29.6 \\
ARA08 QFF-2 & 1.5 & 75.2 & 0 & 23.3 \\
ARA08 QFF-3 & 49.3 & 12.0 & 10.6 & 28.1 \\
ARA08 QFF-4 & 99.7 & 0 & 0.3 & 0 \\
ARA08 QFF-5 & 79.7 & 0.1 & 20.2 & 0 \\
ARA08 QFF-6 & 71.5 & 0 & 28.5 & 0 \\
\hline
\end{tabular}

\subsection{HMW n-Alkanes in Marine Aerosols}

The HMW n-alkanes $\left(\mathrm{C}_{27}-\mathrm{C}_{31}\right)$ were detected in all marine aerosol samples investigated, suggesting an input of terrestrial higher plant leaf waxes [4]. The $\Sigma C_{27-31}$ was higher in the northwest Pacific Ocean $\left(1.4 \pm 1.0 \mathrm{ng} / \mathrm{m}^{3}\right)$ than in the Arctic Ocean $\left(0.05 \pm 0.01 \mathrm{ng} / \mathrm{m}^{3}\right)$, especially close to the East Asian countries (Figure 3C). The carbon number maxima (Cmax) in the $C_{27}-C_{31}$ range can also give an indication of a significant incorporation of higher land plant waxes [31]. The $\mathrm{Cmax}$ at $n-\mathrm{C}_{27}$ and $n-C_{29}$ (Figure 2) with the $\mathrm{ACL}_{27-31}$ of $\sim 29$ (Figure 3D) are thus evidence for an origin of epicuticular leaf waxes of higher land plants. Our results are in line with previous studies that reported a $\mathrm{Cmax}$ at $n-\mathrm{C}_{27}$ in the Arctic marine aerosols [24] and a $\mathrm{Cmax}$ at $n-\mathrm{C}_{29}$ or $n-\mathrm{C}_{31}$ in the Pacific marine aerosols $[10,11]$. The HMW n-alkanes showed $\mathrm{CPI}_{27-31}$ of $3.2 \pm 0.4$ in the Arctic Ocean and of $6.1 \pm 1.1$ in the northwest Pacific Ocean (Figure 3E). Hence, $\mathrm{CPI}_{27-31}$ values ( $>3$ ) demonstrate that the marine aerosols investigated were affected by higher plant waxes. Furthermore, $\% W x_{27-31}$, with values of $48 \pm 5 \%$ in the Arctic Ocean and of $68 \pm 5 \%$ in the Northwest Pacific (Figure 3F), provides evidence of an influence of higher plant leaf waxes in the marine aerosols. Our results demonstrate that the marine aerosols studied were influenced by petroleum residues, as shown by the \%PNA, with a value of $52 \pm 5 \%$ in the Arctic Ocean and $32 \pm 5 \%$ in the northwest Pacific Ocean. Thus, the relative contribution of fossil-fuel combustion to the resolved HWM $n$-alkanes was higher in the Arctic aerosols than in the Pacific aerosols, contrary to that of UCM (see Figure 3A).

The carbon isotopic signatures of $n$-alkanes are a useful means to distinguish between sources $[45,46]$. The $n$-alkane $\delta^{13} \mathrm{C}$ values of higher land plants that use the Calvin-Benson cycle of carbon fixation (i.e., $C_{3}$ plants) were centred at $-34.6 \pm 2.9 \%$ o for $n-C_{27},-35.1 \pm 2.3 \%$ o for $n-C_{29}$, 
and $-35.4 \pm 2.6 \%$ o for $n-C_{31}[38,47-50]$. On the other hand, $C_{4}$ plants that use the Hatch-Slack cycle of carbon fixation exhibit the $n$-alkane $\delta^{13} \mathrm{C}$ values of $-20.8 \pm 2.9 \%$ o for $n-C_{27},-20.0 \pm 2.3 \%$ o for $n-C_{29}$, and $-20.1 \pm 2.5 \%$ o for $n-C_{31}[38,47-50]$. The $\delta^{13} \mathrm{C}$ signatures in the Pacific marine aerosols were within a narrow range of $-32.0 \pm 0.1 \%$ or $n-C_{27},-32.0 \pm 0.4 \%$ for $n-C_{29}$, and $-32.0 \pm 0.2 \%$ for $n-C_{31}$ (Figure 4). In contrast, the Arctic marine aerosols showed relatively larger variations in $\delta^{13} \mathrm{C}$ for $n-\mathrm{C}_{29}$ $(-32.4 \pm 0.7 \%$ o $)$ and $n-C_{31}\left(-34.2 \pm 0.6 \%\right.$ o), except for $n-C_{27}(-30.4 \pm 0.2 \%$ o) (Figure 4$)$. The difference in the same $n$-alkanes between the samples may reflect atmospheric transport pathways and hence differential source areas. However, QFF-1 and QFF-2 collected in the Arctic Ocean showed similar back trajectories with the main sources from the Arctic Ocean and North American countries (Table 2, see also Figure 2) but revealed differences in $\delta^{13} \mathrm{C}$ of $n-\mathrm{C}_{29}$ and $n-\mathrm{C}_{31}$ (see Figure 4). Hence, the relatively high deviation of $\delta^{13} \mathrm{C}$ values among the Arctic aerosol samples seems to be related to the diversity of the wind directions and thus the source regions.

The relative contributions to the HMW $n$-alkanes from terrestrial $C_{3}$ and $C_{4}$ plants were estimated by using a simple two-endmember mixing model [51], based on the $\delta^{13} \mathrm{C}$ values of $n-C_{27}$ : $C_{3}$ plant $n$-alkanes $=-34.6 \%$ ond $\mathrm{C}_{4}$ plant $n$-alkanes $=-20.8 \%$ o. Use of the mixing model resulted in estimates of $\mathrm{C}_{4}$ plant contribution varying from $29 \%$ to $32 \%$ for the Arctic marine aerosols and $17 \%$ to $20 \%$ for the Pacific marine aerosols. Accordingly, the mixing model results suggest a higher input of $\mathrm{C}_{4}$ plants to the Arctic marine aerosols than to the Pacific marine aerosols during the time of sampling. However, it should be noted that there was a negative correlation between $\delta^{13} \mathrm{C}$ ratios of $n-\mathrm{C}_{27}$ against $\mathrm{CPI} 27-31$ $\left(\mathrm{R}^{2}>0.78, p<0.0001\right)$ but a positive correlation between $\delta^{13} \mathrm{C}$ ratios of $n-\mathrm{C}_{27}$ against $\% \mathrm{PNA}_{27-31}$ $\left(R^{2}>0.85, p<0.0001\right)$. Notably, the Arctic marine aerosol samples were separately clustered from the Pacific marine aerosol samples in association with even-carbon-numbered long-chain $n$-alkanes (Figure 5). Hence, this line of evidence in addition to lower $\mathrm{CPI}_{27-31}$ and higher \% $\mathrm{PNA}_{27-31}$ suggests that the contribution of fossil-fuel combustion influenced more strongly the $\delta^{13} \mathrm{C}$ ratios of $n-\mathrm{C}_{27}$ in the Arctic marine aerosols than in the Pacific marine aerosols. Accordingly, it appears that the $\delta^{13} \mathrm{C}$ signatures of HMW $n$-alkanes contained in the marine aerosols analyzed were affected by the contribution of both $C_{3} / C_{4}$ plants and fossil-fuel combustions.

\section{Conclusions}

We investigated molecular distributions and $\delta^{13} \mathrm{C}$ of $n$-alkanes in marine aerosols collected along a transect from the Arctic Ocean to the northwest Pacific Ocean. In all studied samples, the anthropogenic input was evidenced by the presence of UCM, high U/R ratios, and low CPI values for low molecular weight $n$-alkanes. The biogenic input of terrestrial higher plant leaf waxes was predominant for HMW n-alkanes in all studied samples, with high CPI values. The $\delta^{13} \mathrm{C}$ of HMW $n$-alkanes was as a function of the relative contributions from the $C_{3} / C_{4}$ plant sources in addition to the anthropogenic inputs from fossil-fuel combustions. Accordingly, $n$-alkanes in the studied marine aerosol samples originated from mixed sources. The back-trajectory results provided evidence that the atmospheric transport of anthropogenic and biogenic organic materials from North American and East Asian countries contributed to marine aerosols in the Arctic Ocean and the northwest Pacific Ocean, respectively. Accordingly, our results show that changes in molecular distributions and $\delta^{13} \mathrm{C}$ of $n$-alkanes of marine aerosols were a function of changes in the prevailing wind and hence source regions. Furthermore, our study provides a basis for future paleoclimatological work for understanding the link between land-derived HMW $n$-alkanes in the atmosphere and those in the marine sediments in the Arctic Ocean.

Author Contributions: Conceptualization, J.-H.K. and J.P.; methodology, S.-B.K.; trajectory analysis, Y.G.; writing —original draft preparation, J.-H.K.; writing —review and editing, J.P. and K.-H.S.; visualization, J.-H.K. and S.K. All authors have read and agreed to the published version of the manuscript.

Funding: This research received no external funding.

Acknowledgments: We thank two anonymous reviewers for their careful reading of our manuscript. We would like to thank the captain and crew of R/V ARAON for their safe and skillful operation of the ship during the 
cruise. We thank Dahae Kim at KOPRI and Dong-Hun Lee at HYU for their analytical support in the lab. This research was supported by the National Research Foundation of Korea (NRF) grants funded by the Ministry of Science and ICT (MSIT)—South Korea (NRF-2015M1A5A1037243, KOPRI-PN19090 and NRF-2016M1A5A1901769, KOPRI-PN20081).

Conflicts of Interest: The authors declare no conflict of interest. The funders had no role in the design of the study; in the collection, analyses, or interpretation of data; in the writing of the manuscript, or in the decision to publish the results.

\section{References}

1. Simoneit, B.R.T. Organic matter of the troposphere: III. Characterization and sources of petroleum and pyrogenic residues in aerosols over the western United States. Atmos. Environ. 1984, 18, 51-67. [CrossRef]

2. Simoneit, B.R.T. Biomass burning-a review of organic tracers for smoke from incomplete combustion. Appl. Geochem. 2002, 17, 129-162. [CrossRef]

3. Bush, R.T.; McInerney, F.A. Leaf wax $n$-alkane distributions in and across modern plants: Implications for paleoecology and chemotaxonomy. Geochim. Cosmochim. Acta 2013, 117, 161-179. [CrossRef]

4. Eglinton, G.; Hamilton, R.J. Leaf epicuticular waxes. Science 1967, 156, 1322-1335. [CrossRef] [PubMed]

5. Simoneit, B.R.T.; Chester, R.; Eglinton, G. Biogenic lipids in particulates from the lower atmosphere over the eastern Atlantic. Nature 1977, 267, 682-685. [CrossRef]

6. Gagosian, R.B.; Peltzer, E.T.; Zafiriou, O.C. Atmospheric transport of continentally derived lipids to the tropical North Pacific. Nature 1981, 291, 312-314. [CrossRef]

7. Gagosian, R.B.; Peltzer, E.T.; Merrill, J.T. Long-range transport of terrestrially derived lipids in aerosols from the South Pacific. Nature 1987, 325, 800-803. [CrossRef]

8. Schefuß, E.; Ratmeyer, V.; Stuut, J.-B.W.; Jansen, J.F.; Sinninghe Damsté, J.S. Carbon isotope analyses of $n$-alkanes in dust from the lower atmosphere over the central eastern Atlantic. Geochim. Cosmochim. Acta 2003, 67, 1757-1767. [CrossRef]

9. Schreuder, L.T.; Stuut, J.-B.W.; Korte, L.F.; Sinninghe Damsté, J.S.; Schouten, S. Aeolian transport and deposition of plant wax n-alkanes across the tropical North Atlantic Ocean. Org. Geochem. 2018, 115, 113-123. [CrossRef]

10. Simoneit, B.R.T.; Kobayashi, M.; Mochida, M.; Kawamura, K.; Lee, M.; Lim, H.-J.; Turpin, B.J.; Komazaki, Y. Composition and major sources of organic compounds of aerosol particulate matter sampled during the ACE-Asia campaign. J. Geophys. Res. 2004, 109, D19S10. [CrossRef]

11. Bendle, J.; Kawamura, K.; Yamazaki, K.; Niwai, T. Latitudinal distribution of terrestrial lipid biomarkers and $n$-alkane compound-specific stable carbon isotope ratios in the atmosphere over the western Pacific and Southern Ocean. Geochim. Cosmochim. Acta 2007, 71, 5934-5955. [CrossRef]

12. Fu, P.Q.; Kawamura, K.; Miura, K. Molecular characterization of marine organic aerosols collected during a round-the-world cruise. J. Geophys. Res. 2011, 116, D13302. [CrossRef]

13. Westerhausen, L.; Poynter, J.; Eglinton, G.; Erlenkeuser, H.; Sarnthein, M. Marine and terrigenous origin of organic matter in modern sediments of the equatorial East Atlantic: The $\delta^{13} \mathrm{C}$ and molecular record. Deep-Sea Res. I 1993, 40, 1087-1121. [CrossRef]

14. Huang, Y.; Dupont, L.; Sarnthein, M.; Hayes, J.M.; Eglinton, G. Mapping of $C_{4}$ plant input from North West Africa into North East Atlantic sediments. Geochim. Cosmochim. Acta 2000, 64, 3505-3513. [CrossRef]

15. Schefuß, E.; Versteegh, G.J.; Jansen, J.; Sinninghe Damsté, J.S. Lipid biomarkers as major source and preservation indicators in SE Atlantic surface sediments. Deep-Sea Res. I 2004, 51, 1199-1228. [CrossRef]

16. Ohkouchi, N.; Kawamura, K.; Kawahata, H.; Taira, A. Latitudinal distributions of terrestrial biomarkers in the sediments from the Central Pacific. Geochim. Cosmochim. Acta 1997, 61, 1911-1918. [CrossRef]

17. Kim, J.-H.; Lee, D.-H.; Yoon, S.-H.; Jeong, K.-S.; Choi, B.; Shin, K.-H. Contribution of petroleum-derived organic carbon to sedimentary organic carbon pool in the eastern Yellow Sea (the northwestern Pacific). Chemosphere 2017, 168, 1389-1399. [CrossRef]

18. Ohkouchi, N.; Kawamura, K.; Takemoto, N.; Ikehara, M.; Nakatsuka, T. Implications of carbon isotope ratios of $\mathrm{C}_{27}-\mathrm{C}_{33}$ alkanes and $\mathrm{C}_{37}$ alkenes for the sources of organic matter in the Southern Ocean surface sediments. Geophys. Res. Lett. 2000, 27, 233-236. [CrossRef] 
19. Bird, M.I.; Summons, R.E.; Gagan, M.K.; Roksandic, Z.; Dowling, L.; Head, J.; Fifield, L.K.; Cresswell, R.G.; Johnson, D.P. Terrestrial vegetation change inferred from $n$-alkane $\delta^{13} \mathrm{C}$ analysis in the marine environment. Geochim. Cosmochim. Acta 1995, 59, 2853-2857. [CrossRef]

20. Madureira, L.A.S.; van Kreveld, S.A.; Eglinton, G.; Conte, M.H.; Ganssen, G.; van Hinte, J.E.; Ottens, J.J. Late Quaternary high-resolution biomarker and other sedimentary climate proxies in a Northeast Atlantic core. Paleoceanography 1997, 12, 255-269. [CrossRef]

21. Schefuß, E.; Schouten, S.; Jansen, J.H.F.; Sinninghe Damsté, J.S. African vegetation controlled by tropical sea surface temperatures in the mid-Pleistocene period. Nature 2003, 422, 418-421. [CrossRef] [PubMed]

22. Hughen, K.A.; Eglinton, T.I.; Xu, L.; Makou, M. Abrupt tropical vegetation response to rapid climate changes. Science 2004, 304, 1955-1959. [CrossRef] [PubMed]

23. Uno, K.T.; Polissar, P.J.; Jackson, K.E.; deMenocal, P.B. Neogene biomarker record of vegetation change in eastern Africa. Proc. Natl. Acad. Sci. USA 2016, 113, 6355-6363. [CrossRef] [PubMed]

24. Fu, P.Q.; Kawamura, K.; Chen, J.; Charrière, B.; Sempéré, R. Organic molecular composition of marine aerosols over the Arctic Ocean in summer: Contributions of primary emission and secondary aerosol formation. Biogeosciences 2013, 10, 653-667. [CrossRef]

25. Park, J.; Dall'Osto, M.; Park, K.; Gim, Y.; Kang, H.J.; Jang, E.; Park, K.-T.; Park, M.; Yum, S.S.; Jung, J.; et al. Shipborne observations reveal contrasting Arctic marine, Arctic terrestrial and Pacific marine aerosol properties. Atmos. Chem. Phys. Discuss. 2019. [CrossRef]

26. Rolph, G.; Stein, A.; Stunder, B. Real-time Environmental Applications and Display sYstem: READY. Environ. Modell. Softw. 2017, 95, 210-228. [CrossRef]

27. Dall'Osto, M.; Park, J.; Kim, J.-H.; Kang, S.-H.; Park, K.; Bessows, D.C.S.; Harrison, R.M.; Yoon, Y.J. Arctic ship-based evidence of new particle formation events in the Chukchi and East Siberian Seas. Atmos. Environ. 2020, 223, 117232. [CrossRef]

28. Pang, X.; Pu, J.; Zhao, X.; Ji, Q.; Qu, M.; Cheng, Z. Comparison between AMSR2 sea ice concentration products and pseudo-ship observations of the Arctic and Antarctic sea ice edge on cloud-free days. Remote Sens. 2018, 10, 317. [CrossRef]

29. Cranwell, P.A.; Eglinton, G.; Robinson, N. Lipids of aquatic organisms as potential contributors to lacustrine sediments-II. Org. Geochem. 1987, 11, 513-527. [CrossRef]

30. Bray, E.E.; Evans, E.D. Distribution of $n$-paraffins as a clue to recognition of source beds. Geochim. Cosmochim. Acta 1961, 22, 2-15. [CrossRef]

31. Simoneit, B.R.T.; Cardoso, J.N.; Robinson, N. An assessment of terrestrial higher molecular weight lipid compounds in aerosol particulate matter over the South Atlantic from about 30-70 ${ }^{\circ}$. Chemosphere 1991, 23, 447-465. [CrossRef]

32. Yadav, S.; Tandon, A.; Attri, A.K. Monthly and seasonal variations in aerosol associated $n$-alkane profiles in relation to meteorological parameters in New Delhi, India. Aerosol Air Qual. Res. 2013, 13, 287-300. [CrossRef]

33. R Development Core Team. R: A Language and Environment for Statistical Computing; R Foundation for Statistical Computing: Vienna, Austria, 2015; Available online: http://www.R-project.org (accessed on 17 July 2018).

34. Boyer, K.K.; Laitinen, H.A. Automobile exhaust particles: Properties of environmental significance. Environ. Sci. Technol. 1975, 9, 457-459. [CrossRef]

35. Simoneit, B.R.T.; Mazurek, M.A. Air pollution: The organic components. Crit. Rev. Environ. Control. 1981, 11, 219-276. [CrossRef]

36. Gough, M.A.; Rowland, S.J. Characterization of unresolved complex mixtures of hydrocarbons in petroleum. Nature 1990, 344, 648-650. [CrossRef]

37. Kawamura, K.; Ishimura, Y.; Yamazaki, K. Four years observations of terrestrial lipid class compounds in marine aerosols from the western North Pacific. Global Biogeochem. Cycles 2003, 17, 1003. [CrossRef]

38. Bendle, J.A.; Kawamura, K.; Yamazaki, K. Seasonal changes in stable carbon isotopic composition of $n$-alkanes in the marine aerosols from the western North Pacific: Implications for the source and atmospheric transport. Geochim. Cosmochim. Acta 2006, 70, 13-26. [CrossRef]

39. Tao, S.; Yin, X.; Jiao, L.; Zhao, S.; Chen, L. Temporal variability of source-specific solvent-extractable organic compounds in coastal aerosols over Xiamen, China. Atmosphere 2017, 8, 33. [CrossRef] 
40. Fu, P.Q.; Kawamura, K.; Barrie, L.A. Photochemical and other sources of organic compounds in the Canadian high Arctic aerosol pollution during winter-spring. Environ. Sci. Technol. 2009, 43, 286-292. [CrossRef]

41. Mazurek, M.A.; Simoneit, B.R.T. Characterization of biogenic and petroleum-derived organic matter in aerosols over remote, rural and urban areas. In Identification and Analysis of Organic Pollutants in Air; Keith, L.H., Ed.; Ann Arbor Science/Butterworth: Boston, MA, USA, 1984; pp. 353-370.

42. Azevedo, D.A.; Moreira, L.S.; Siqueira, D.S. Composition of extractable organic matter in aerosols from urban areas of Rio de Janeiro city, Brazil. Atmos. Environ. 1999, 33, 4987-5001. [CrossRef]

43. Tang, X.L.; Bi, X.H.; Sheng, G.Y.; Tan, J.H.; Fu, J.M. Seasonal variation of particle size distribution of $n$-alkanes and polycyclic aromatic hydrocarbons (PAHs) in urban aerosol of Guangzhou, China. Environ. Monit. Assess. 2006, 117, 193-213. [CrossRef] [PubMed]

44. Tissot, B.P.; Welte, D.H. Petroleum Formation and Occurrence: A New Approach to Oil and Gas Exploration, 2nd ed.; Springer: Berlin, Germany, 1984; pp. 1-702. [CrossRef]

45. Freeman, K.H.; Hayes, J.M.; Trendel, J.M.; Albrecht, P. Evidence from carbon isotope measurements for diverse origins of sedimentary hydrocarbons. Nature 1990, 343, 254-256. [CrossRef] [PubMed]

46. Collister, J.W.; Summons, R.E.; Lichtfouse, E.; Hayes, J.M. An isotopic biogeochemical study of the Green River oil shale. Org. Geochem. 1992, 19, 265-276. [CrossRef]

47. Collister, J.W.; Rieley, G.; Stern, B.; Eglinton, G.; Fry, B. Compound-specific $\delta^{13} \mathrm{C}$ analyses of leaf lipids from plants with differing carbon dioxide metabolisms. Org. Geochem. 1994, 21, 619-627. [CrossRef]

48. Huang, Y.; Eglinton, G.; Ineson, P.; Latter, P.M.; Bol, R.; Harkness, D.D. Absence of carbon isotope fractionation of individual $n$-alkanes in a 23-year field decomposition experiment with Calluna vulgaris. Org. Geochem. 1997, 26, 497-501. [CrossRef]

49. Lockheart, M.J.; VanBergen, P.F.; Evershed, R.P. Variations in the stable carbon isotope compositions of individual lipids from the leaves of modern angiosperms: Implications for the study of higher land plant-derived sedimentary organic matter. Org. Geochem. 1997, 26, 137-153. [CrossRef]

50. Chikaraishi, Y.; Naraoka, H. Compound-specific $\delta \mathrm{D}-\delta^{13} \mathrm{C}$ analyses of $n$-alkanes extracted from terrestrial and aquatic plants. Phytochemistry 2003, 63, 361-371. [CrossRef]

51. Chesselet, R.; Fontugne, M.; Buat-Ménard, P.; Ezat, U.; Lambert, C.E. The origin of particulate organic carbon in the marine atmosphere as indicated by its stable carbon isotopic composition. Geophys. Res. Lett. 1981, 8, 345-348. [CrossRef] 